\title{
Bokrecension: Creative Writing for Critical Thinking. Creating a Discoursal Identity
}

\author{
Lennart Hellspong* \\ Institutionen för kultur och lärande, Södertörns högskola \\ Edberg, Hélène (2018). Creative Writing for Critical Thinking. Creating a Discoursal \\ Identity. Palgrave, Macmillan, 4I6 s. https://doi.org/I0.I007/978-3-319-6549I-I
}

Kreativt skrivande finns som poänggivande kurser vid många högskolor. De studenter som söker sig dit har ofta skönlitterära författardrömmar. Det rör sig alltså om ett annat slags skrivande än det rent vetenskapliga. Därför kunde det ses som lite udda i en akademisk miljö. Men kanske knyter det ändå an till högskolans grunduppgifter? Den frågan har Helene Edberg försökt besvara i Creative Writing for Critical Thinking.

Kritiskt tänkande hör till det som universitetslärare förväntas stimulera hos sina studenter. Själva begreppet är långt ifrån självklart och har getts olika betydelser, från att genomskåda logiska och metodologiska fel i vetenskapliga undersökningar till att pröva sina egna fördomar och förutfattade meningar.

Det senare synsättet har bland andra betonats av den amerikanska filosofen Martha Nussbaum. För henne är kärnan i det kritiska tänkandet att kunna ifrågasätta sina egna sociala och kulturella stereotyper. Till hjälp för att bli mer vidsynta kan vi använda den inkännande fantasi som Nussbaum kallar "narrative imagination". Den kan odlas och övas bland annat genom att läsa och samtala om god litteratur. I sin studie undersöker Edberg om inte även eget berättande kan motverka kulturell och social självcentrering, allra helst om det utgår från teman som konfronterar givna föreställningar, normer och värderingar. Studien baseras på Edbergs erfarenheter från en kurs i kreativt skrivande.

Som ett pedagogiskt experiment fick studenterna bland sina uppgifter också möta ett moraliskt dilemma. En ensamstående småbarnsförälder erbjuds ett arbete som kräver att hen är borta från barnet under två år. Med den givna förutsättningen skulle deltagarna skriva en berättelse följd av en reflexionstext med sina spontana tankar om vad uppgiften krävt av dem. Därefter fick de delta i en gruppdiskussion med ett antal kamrater, som läst deras text. Senare fick de skriva en reviderad text plus en fördjupad reflexionstext, där de funderade över sitt skrivande och vad de lärt sig av uppgiften och gruppsamtalet. Det hela avslutades med en lärarledd lektion.

Den experimentella skrivuppgiften skulle alltså utföras i två steg. Det första vädjade till fantasi och emotionell inlevelse, medan det andra krävde kritisk eftertanke. I övningens pedagogiska fokus stod att utveckla "kritisk litteracitet" (jfr Nussbaums betoning av att ifrågasätta sociala och kulturella stereotyper). I en förkortad variant prövades upplägget också inom lärarutbildningen.

*Författarkontakt: lennart.hellspong@sh.se

Artiklar och reflektioner är kollegialt granskade. Övriga bidragstyper granskas av redaktionen. Se https://hogreutbildning.se ISSN 2000-7558

(C)2019 Lennart Hellspong. This is an Open Access article distributed under the terms of the Creative Commons Attribution-NonCommercial 4.0 International License (https://creativecommons.org/licenses/by-nc/4.0/), allowing third parties to share their work (copy, distribute, transmit) and to adapt it, under the condition that the authors are given credit, that the work is not used for commercial purposes, and that in the event of reuse or distribution, the terms of this license are made clear.

Citation: Lennart Hellspong (2019) “Bokrecension: Creative Writing for Critical Thinking. Creating a Discoursal Identity», Högre utbildning, 9(1), 34-37. https://doi.org/10.23865/hu.v9.1505 
Den första studien, som pågick under ett par terminer, resulterade i 47 reflexionstexter, den andra i I8. Utöver dessa tillkom alltså även de transkriberade gruppsamtalen som underlag för Edbergs analys.

\section{TEORETISKA UTGÅNGSPUNKTER}

För att analysera studenternas metareflexioner kring sitt skrivande valde Edberg att utnyttja aktivitetsteorin utvecklad av Vassilij Leontiev, senare vidareutvecklad av bl.a. Yrjö Engeström. Teorin har sina rötter i Lev Vygotskijs syn på inlärning som en social process som inte kan förstås och förklaras utanför sin specifika kontext.

Aktivitetsteorin har framför allt brukats för att beskriva verksamheter inom en organisation. Där samarbetar olika subjekt med varierande motiv för att genom bruk av olika redskap uppnå vissa mål. Det sker inom ramen för en gemenskap, där det finns regler och en arbetsdelning som påverkar arbetets resultat.

Den stora fördelen med aktivitetsteorin i detta sammanhang är att den sätter in skrivandet i en kontext med specificerade element som kan vara av intresse för att analysera läroprocessens förutsättningar. Då framträder också möjliga spänningar och konflikter som kan påverka verksamhetens resultat. Som exempel kan vi peka på momentet mål. En skrivkurs har givetvis ett officiellt mål, men utöver det finns lärarens eget mål liksom studenternas personliga mål, som förstås kan variera och skilja sig från vad läraren uppfattar som kursens syfte.

Aktivitetsteorin har sedan kompletterats med en diskursteori för att medge en analys av deltagarnas textuella redskap. Teorin är inspirerad av Mihail Bahtins syn på texter som medel för en inre dialog. Ett centralt begrepp för Edberg är här diskursidentitet, hämtat från Ros Ivanič. Det rör sig om en specifik identitet som utvecklas i ett samspel mellan skribenten och hennes skrivande omgivning. Identiteten befinner sig liksom lärandet hela tiden i utveckling. I en text uttrycks identiteten som ett diskursjag och representerar i Edbergs tolkning aktivitetsmodellens subjekt. Ivanič ser den lärandes önskan att identifiera sig med människor som ägnar sig åt en viss aktivitet som en stark drivkraft för inlärningen. Edberg utgår alltså från identitetsbildningens betydelse för läroprocessen. Det innebär att en deltagares syn på sig själv som skrivande person kan påverka hur och hur väl hon lyckas utnyttja kursen.

\section{GENOMFÖRANDE OCH RESULTAT}

I sin analys använder Edberg sin komplexa begreppsapparat för att kategorisera innehållet $\mathrm{i}$ reflektionstexterna och gruppdiskussionerna med hänsyn till den typ av diskursjag som framträder i dem, de teman och sociala ramar som är aktuella och det inslag i aktivitetsmodellen som står i fokus. Detta möjliggör en synnerligen detaljerad beskrivning ner på meningsnivå av deltagarnas olika förhållningssätt till skrivuppgiften.

En nackdel kan vara att klassificeringen blir ganska oöverskådlig genom sin stora komplexitet. Samtidigt är denna explorativa undersökning av hur skribenternas förhållningssätt till sin uppgift kan karaktäriseras på ett didaktiskt meningsfullt och intressant sätt av stort värde. Med tanke på att det undersökta materialet trots allt är ganska begränsat får de resultat som Edberg kommer fram till närmast ses som prov på vad man kan urskilja vid en analys av förhållningssätt som kan vara didaktiskt intressanta.

Låt mig ge några exempel på sådana resultat. På kursen i kreativt skrivande kunde deltagarna till exempel positionera sig som "lärjungar" eller "författare". I det förra fallet bedömde de vad uppgiften hade betytt för att utveckla deras skrivande. I det senare fallet såg de snarare på sitt skrivande utifrån en jämförelse med vad man kunde vänta sig av en professionell författare. 


\section{Lennart Hellspong}

Det är naturligtvis svårt att dra några slutsatser om vilket förhållningssätt som är mest fruktbart för lärande (allra helst som samma person kunde ge uttryck för båda i olika delar av samma yttrande). Kanske har lärjungepositionen betydelse för att utforska sina egna utvecklingsmöjligheter, för att experimentera och pröva sig fram och för att lära sig nya förhållningssätt och grepp, och författarpositionen för att ta sin uppgift på fullaste allvar och mäta sig med de professionella aktörerna.

Också lärarstudenterna intog olika diskurspositioner i sina kommentarer till uppgiften. Många bedömde den utifrån sin blivande lärarroll, nämligen med tanke på hur lämplig och stimulerande den kunde vara för deras blivande elever. Men andra såg också på den som författare och bedömde hur utvecklande den kändes för deras eget skrivande.

Nussbaum rekommenderar läsning av god litteratur och diskussion kring den som en metod för att utveckla elevernas sinne för hur komplicerade frågor kan ses ur andra perspektiv än de mest vanliga och konventionella i vår kultur. Edbergs motbud är att använda skrivande för att träna "att gå i andras skor". Deltagarnas kommentarer tyder på att de i sina reflektioner kring uppgiften blir medvetna om etniska, sociala och andra förhållanden som de i första hand kanske inte har tänkt på.

Det hade varit intressant att utöver exemplen med deras kvalitativt inriktade analyser också få en kvantitativ redovisning av hur vanliga sådana självkritiska anmärkningar var bland studenterna. Förekom de hos alla eller bara hos vissa, och går eventuella skillnader att på något sätt förstå och förklara inom Edbergs egen teoriram?

För att få ett grepp om sitt material har Edberg delat in det i enheter (yttranden) av växlande längd, från en kort fras till flera meningar i utskriften. I kapitel 6-8 har nära nog alla sådana yttranden (det rör sig om ett mycket stort antal) fătt en egen specialrubrik i materialgenomgången. Vart och ett av dem följs av en tolkande kommentar som relaterar det till teoriramen. Låt mig som exempel anföra en av de kortare analyserna (från s. 246):

93 Perspective change going from lived experience to fiction

[...] the fact that I chose to write from a mother's point of view is because I am a mother myself, and I related to my own emotions, if I were forced to leave my child. [...] (Erika)

The changes of perspective in example (93) may seem trivial. Erika transforms her own experience into fiction. However, perspective changes are very likely not to be the least bit trival to subjects themselves. They would not have occurred had it not been for the surrounding texts. Which causes Erika to see, or analyze, her preferred choices. This is a sign of appropriation, an incipient critical insight about oneself as a writer and about what subconscious attitudes influence one's argument. In the process-oriented position, themes in the metareflection link to these types of personal experiences or emotions from experience that the fictitious characters in the narratives go through."

Det rör sig alltså om en mycket materialnära analys, som förenar själva materialets konkretion med de möjligheter till abstraktion och generalisering som den teoretiska ramen ger. Edbergs analyser är genomgående synpunktsrika, tänkvärda och fint nyanserade. De visar på ett övertygande sätt hur en genomtänkt teori kan skärpa observationsförmågan.

\section{PEDAGOGISKA SLUTSATSER}

Edbergs skarpsinniga och idérika bok är värdefull på många plan. Först och främst ter den sig oumbärlig för alla som på allvar vill sätta sig in i de pedagogiska förutsättningarna för kurser i kreativt skrivande. Också på ett praktiskt plan kan den hjälpa en lärare att förstå hur hon via studentproducerade reflexionstexter, enskild handledning och gruppdiskussioner kan undersöka 
vad studenterna har för skrivrelaterade attityder och föreställningar som kan vara viktiga för hur och vad de lär sig på kursen.

En annan stor förtjänst är att Edberg har berikat aktivitetsteorin med en omfattande begreppsapparat för att karaktärisera pedagogiska aktiviteters diskursiva dimension. Den kan vara särskilt användbar för skrivkurser men kan också förtjäna att prövas i andra sammanhang. Mer allmänt motsvarar de diskursjag eller diskursidentiteter som Edberg diskuterar olika möjliga subjektidentiteter som kan utkristalliseras i vilken undervisningssituation som helst.

Boken ger vidare insikter som kunde användas för att stimulera kritiskt tänkande (fördomsbekämpning, vidgade perspektiv) även i ungdomsskolan, genom narrativt skrivande och diskussion kring det skrivna. Den inbjuder också till fortsatta undersökningar. Hur kan t.ex. olika typer av dilemman påverka den kritiska reflektionen? Vad händer om två eller flera deltagare får samarbeta om skrivuppgiften? Hur förhåller sig resultatet av Edbergs arbetssätt till om deltagarna först får diskutera ett dilemma tillsammans och sedan skriva om det? Hur berikas eller försvagas den kritiska reflexionen om deltagarna får skriva argumenterande i stället för berättande texter? Det vore också intressant att genomföra en verkligt longitudinell undersökning med fler uppgifter av liknande typ som Edberg prövat för att se om det sker en successiv fördjupning av förmågan till kritisk litteracitet.

Den presentation som jag gjort här har bara kunnat antyda det rika innehållet i Edbergs bok. Även om den kanske inte pekar ut några entydiga resultat eller vägar att gå framåt inom pedagogiken är den mycket inspirerande och ger många uppslag att pröva. Till det kommer att den är synnerligen välskriven, med en klar, enkel och behaglig prosa som lämpar sig väl för nyanserade och subtila resonemang. Den gör boken till ett fint exempel på vad en tolkande studie av pedagogiska processer kan uppnå, när den förfogar över de rätta redskapen.

(Hélène Edberg har tidigare arbetat med Lennart Hellspong på Södertörns högskola. Reds anm.) 